\title{
Surveying the Pleistocene Humans in Anatolia: The Latest Studies
}

\author{
Ahmet İhsanaytek* \\ Mehmet Akif Ersoy University, Faculty of Arts and Science, Department of Anthropology, Turkey
}

Submission: December 12, 2017; Published: March 29, 2018

*Corresponding author: Ahmet İhsanaytek, Mehmet Akif Ersoy University, Faculty of Arts and Science, Department of Anthropology, Burdur, Turkey, Email: aytek@mehmetakif.edu.tr

\begin{abstract}
The timing and route of early human dispersals out of the African continent are among the most important issues currently discussed in paleoanthropology. Several questions arise concerning both early and later dispersals: When did migration events happen? From which populations did these dispersing hominins stem? Which routes did they use? One of the likely dispersal corridors passes through Turkey, which is situated among three continents and therefore can be seen as an important bridge among them. Despite its geographic position, paleoanthropological and archaeological research for Pleistocene period in Turkey has been limited, and the known fossil human record from this region is small. Although most of the known fossil human remains were found during early investigations, in the last decade new finds have further highlighted the region's potential for paleoanthropological and archaeological research. This article reviews the latest studies from Turkey, which are focused on Pleistocene human patterns.
\end{abstract}

Keywords: Anatolia; Pleistocene; Paleoanthropology; Palaeolithic; Survey

\section{Introduction}

Anatolia lies directly on one of the likely dispersal corridors from Africa and the Near East into Europe. Hominin fossil finds from Turkey can therefore help in answering questions about hominin dispersals, both for the dispersal event of early Homo species, as well as for the later Out of Africa migration of modern humans. Despite its critical geographic position, paleoanthropological and archaeological research on Pleistocene humans in Turkey has been limited, and the known fossil human record from this region is small. The most important reason of this limitation is the denseness of classical period archaeological sites in Turkey. Turkey has substantial potential for Palaeolithic sites, it is most likely that the poor fossil record is a consequence of the scarcity of excavations and surveys. According to The Archaeological Settlements of Turkey (www.tayproject.org), there have been currently an estimated 488 known Palaeolithic sites in the country, and the number is expected to rise as research efforts intensify. Despite this number, there are just seven sites which yields Palaeolithic human remains; Kocabaş village from Denizli, Karain Cave and Beldibi Rock shelter from Antalya, Merdivenli Cave, Kanal Cave, İncili Cave and Üçağızlı Cave from Hatay [1]. Although this period has been underestimated for a long time, Pleistocene and Palaeolithic surveys have started to increase in recent years, especially in the last five years. In Turkey, this kind of studies are conducted by the anthropologists and archaeologist with the permission of the Ministry of Culture and Tourism. And these studies are open to foreign researchers as well. This mini review aims to summarize the latest Palaeolithic surveys in Anatolia. In this review, the surveys are mentioned which yields the evidence of human existence.

\section{The Latest Studies}

In the recent years, the efforts on Pleistocene and Palaeolithic surveys have been increasing and these studies don't just focus on the specific provinces but also different regions of Anatolia. The surveys which yield material are listed below in a provincial order from the eastern to western Turkey.

\section{Van}

Themostdetailedsurveystudy, in respect of Palaeolithiclithics, comes from Van. Baykara et al. conducted survey in 2014 and 2015. They described Lower Palaeolithicobsidian uni and bifaces, Clactonian flakes, Levallois core, flakes, blade and choppers, Middle Palaeolithic obsidian tool, Levallois core and flakes [2-3].

\section{Gaziantep}

In 2011, Güleçet al. found the material from Lower to Upper Palaeolithic. These are; Levallois cores, bifaces, Acheuleen hand axes, flakes, blades, side scrapers, end scrapers, Clactonian flakes and side scrapers [4]. 


\section{Şanlıurfa}

Middle Palaeolithic bifaces, Levallois points and some other Lower Palaeolithic materials (no more information is given) were found by Çelik in 2013 and 2015 [5-6].

\section{Hatay}

Güleç et al. conducted surveys in Hatay [7-8]. Hatay is also important since it has four different caves which yields humans remains [1]. The team found a lot of raw materials, workshops, Middle Palaeolithic Levallois cores, possible Lower Palaeolithic tools with broad edges and bifaces and some other materials which were attributed to Lower and Middle Palaeolithic [7-8].

\section{Niğde}

Levallois thick flakes and a side scraper which could be dated to Paleolitic were found during the fieldwork in 2015 [9].

\section{Aksaray}

Yamanet al. found Lower Palaeolithic flakes, Lower-Middle Palaeolithic probably Levallois core and Abbevilien biface which is not certain [10].

\section{Çorum}

Middle Palaeolithic core, flake, blade and chopper, Lower Palaeolithic flakes found in 2015 survey in Çorum [11].

\section{Zonguldak}

Zonguldak survey yielded core, blade and scrapers which could be attributed to Middle Palaeolithic [12].

\section{Sakarya}

Sakarya surveys yield an abundant material from Lower to Upper Palaeolithic [13-14]. Levallois cores, Clactonian flakes, Levallois points and cores, chopping tools, scrapers, MiddleUpper transition or Upper Palelithic prismatic blade cores and typical Middle Palaeolithic Mousterian side scrapers were found in 2013 and 2014.

\section{Denizli}

Denizli is the one of the most important province for the Palaeolithic research since the oldest human remain from Turkey was found there. Özçelik et al. conducted fieldwork in 2015 and 2016 in the area and found Clactonien flakes, cores, chopper, Lower Palaeolithic Acheuleen bifaces, Lower-Middle Palaeolithic cores, end scrapers, Levallois cores, Levallois ends Middle Palaeolithic Mousterien point, side scraper and flakes [15-16].

\section{Muğla}

Mugla et al. found a flint stone flake which could be dated to Palaeolithic during their survey in 2013 [17].

\section{Çanakkale}

Canakkale et al. conducted a survey in Çanakkale and found flakes and blades probably dated to Lower/Middle Palaeolithic,
LowerPalaeolithic flakes and cores, late Middle Palaeolithic cores, flakes and hand axesand Early Upper Palaeolithic end scraper, chisel, blade, backed knife and cores [18-19].

\section{Conclusion}

Despite its potential for Pleistocene humans and their Palaeolithic culture, finds are not abundant since this period has been underestimated for a long time. Fortunately, Turkish prehistory made a leap in last years and anthropologists/ archaeologist started to survey in the localities for this very important period. Each year a new Pleistocene/Palaeolithic survey is started and thus the importance of the region is highlighted day by day. It is known that at least three human species habituated in the different parts of Anatolia during Pleistocene period, but the fossil record is sparse and these finds are generally located on the Mediterranean cost [1]. But the lithic record shows another story since they can be found in the whole Anatolia. This implies that humans spread to whole Anatolia during the Pleistocene period. It would be not so surprising if the new fossil material is found in next years.

\section{References}

1. Aytek AI, Harvati K (2016) The Human Fossil Record from Turkey. In: Harvati K, Roksandic M (Eds.), Paleoanthropology of the Balkans and Anatolia: Human evolution and its contex, Springer, Dordrecht, Netherland p. 79-91.

2. Baykara I (2015) Yili Van Ili Neojenve Pleistosen Donemleri Yuzey Arastirmasi Arastirma Sonuclari Toplantisi 2: 539-552.

3. Baykara I, Dinçer B, Sahin S, Baykara D, Bolkan IH (2015) Yili Van IliPleistosen Donem Yuzey Arastırması Arastırma Sonuclari Toplantısı 1: $295-314$.

4. Güleç E, Ozer İ, Sağır M, Baykara İ, Şahin S (2012) Yılı Gaziantep veHatayillleri Yüzey Araștırması Araştırma Sonuçları Toplantısı 2: 257266.

5. Çelik B (2014) Şanlıurfa İli Merkezillçesi Neolitik Çağve Öncesi Yüzey Araştırması Araştırma Sonuçları Toplantısı 2: 311-329.

6. Çelik B (2016) Yılı Şanlıurfa İli Merkezİlçesi Neolitik Çağve Öncesi Yüzey Araştırması. Araştırma Sonuçları Toplantısı 2: 337-358.

7. Güleç E, Özer İ, Baykara İ, Şahin S, Baykal G (2011) YılıMuğla, DenizliveHatayillleri Yüzey Araştırması. Araştırma Sonuçları Toplantısı 3: 171-182.

8. Güleç E, Sağır M, Özer İ, Şahin S, Baykara İ (2013) 2012YılıKonyave Hataylllleri Yüzey Araştırması. Araştırma Sonuçları Toplantısı 1: 90-98.

9. Balcı S, Çakan YG (2016) Niğde Tarihöncesi Yüzey Araştırmaları 2015. Araştırma Sonuçları Toplantısı 2: 1-24.

10. Yaman İD, Aydın, Y, Yaman IA (2016) Aksaray İli Paleolitik ÇağYüzey Araștırmaları Araștırma Sonuçları Toplantısı 1: 111-122.

11.Sağır M, Özer İ, Baykara İ, Şahin S, Sağır S (2016) Yılı Kırıkkaleve Çorumilleri Yüzey Araștırması Araștırma Sonuçları Toplantısı 1: 281294.

12. Baysal A (2015) Zonguldak Ereğlisi Prehistorik Yüzey Araștırması: 2014 Yılı Araştırma Raporu. 33. Araştırma Sonuçları Toplantısı 2: 563580.

13. Kartal M, Karakoç M, Erbil E(2014)Sakarya İli Tarih Öncesi Arkeolojisi Yüzey Araştırması (I), Araștırma Sonuçları Toplantısı 1: 9-26. 
14. Kartal M, Erbil E (2016) Sakarya İli Tarih Öncesi Arkeolojisi Yüzey Araștırması (Iıı), Araştırma Sonuçları Toplantısı 2: 87-100

15. Özçelik K, Kartal G, Fındık B(2015) Denizli İli Prehistorik Dönem Yüzey Araştırması, 2014. Araştırma Sonuçları Toplantısı 1: 377-398.

16. Özçelik K, Vialet A, Bulut H (2016) Denizli İli Prehistorik Dönem Yüzey Araştırması, 334 Araştırma Sonuçları Toplantısı 1: 505-524.

17. Özer İ, Sağır M, Şahin S, Baykara İ, Güleç E (2014) Yılı Muğlave Çanakkale İlleri Yüzey Araştırması. Araștırma Sonuçları Toplantısı 2 : 279-288.
18. Özer İ, Baykara İ, Dinçer B, Sahin S, Sağır M, Güleç E (2015) Yılı Muğlave Çanakkaleİlleri Yüzey Araştırması. Araştırma Sonuçları Toplantısı 2: 323-334.

19. Özer İ, Sağır M, Dinçer B, Şahin S, Baykara İ, Güleç E (2016) Yılı Muğlave Çanakkaleİlleri Yüzey Araștırması. Araştırma Sonuçları Toplantısı 1: 315-329.

\section{Your next submission with Juniper Publishers will reach you the below assets}

- Quality Editorial service

- Swift Peer Review

- Reprints availability

- E-prints Service

- Manuscript Podcast for convenient understanding

- Global attainment for your research

- Manuscript accessibility in different formats

( Pdf, E-pub, Full Text, Audio)

- Unceasing customer service

Track the below URL for one-step submission https://juniperpublishers.com/online-submission.php 